\title{
Matematikte Dört İşlem Becerisinin Geliştirilmesi için Dijital Oyun Tasarımı ve Öğrenci Başarısına Etkileri
}

\author{
Hayri INCEKARA ${ }^{*}$,a Şakir TAŞDEMIR ${ }^{\mathrm{b}}$ \\ ${ }^{a,}{ }^{*}$ Selçuk Üniversitesi Fen Bilimleri Enstitüsü, KONYA 42003, TÜRKIYY \\ ${ }^{b}$ Selçuk Üniversitesi Teknoloji Fakültesi Bilgisayar Mühendisliği Bölümü, KONYA 42003, TÜRKIYE
}

\section{MAKALE BÍLGISI \\ Alınma: 02.10.2019 \\ Kabul: 26.11 .2019

Anahtar Kelimeler:
Dijital Oyun, Dört
İşlem Ögrenme,
Eğitsel Oyun Tasarımı
"Sorumlu Yazar:
e-posta:
incekara86@hotmail.c
om

ÖZET

\begin{abstract}
Bilgisayar destekli dijital oyunları oynayanların sayısı ve oyuncuların oyun başında geçirdikleri süre her geçen gün artmaktadır. Bu sürelerin daha verimli bir şekilde geçirilebilmesi için motivasyon gücü yüksek olan oyunların eğitim sürecinde kullanılması gerekmektedir. Böylece öğrenci hoşça vakit geçirirken öğretilmek istenilen konuyu öğrenebilecek, oyun ortamı ile öğrencideki kaygı azalacak ve bireyselleştirilmiş öğrenme ile öğrencide oluşan yapamama korkusu yenilebilecektir. Bu çalışmada, C\# programlama dili kullanılarak bir yılan oyunu tasarımı gerçekleştirilmiştir. Bu oyun temel öğretim kademesindeki 3. ve 4. sınıf öğrencilerinden 123 öğrenciye oynatılmıştır. Yapılan çalışma ile matematikte dört işlem konusu, y1lan oyunu ile birleştirilerek eğitimin eğlenceli bir şekilde gerçekleştirilmesi amaçlanmıştır. Bu amaçla bir eğitsel yılan oyunu tasarlanmış, oynatılmış ve tasarlanan oyun ile ilgili anket soruları bir araştırma çerçevesinde ilköğretim 3. ve 4. sınıfa giden 123 öğrenciye uygulanmıştır. Alınan cevaplar istatistiksel olarak değerlendirilmiş ve sonuçlar incelenmiştir. Yapılan araştırma sonucuna göre öğrencilerin \%85'i yapılan çalışmanın matematikte dört işlem konusunu anlamada ve bildiklerini geliştirmekte faydalı olduğunu belirtmişlerdir.
\end{abstract}

\section{The Design Of A Digital Game For Developing Four Operations Skills In Mathematics And Its Effects On Student Success}

\section{ARTICLE \\ INFO}

Received: 02.10 .2019

Accepted: 26.11 .2019

\section{Keywords: \\ Digital Game, Four operations learning, Educational Game Design

"Corresponding
Authors
e-mail:
incekara86@hotmail.c
om om}

\begin{abstract}
The number of people who play computer-aided digital games and the amount of time the players spend at the game is increasing day by day. To pass these periods more efficiently, the games with high motivation should be used in the educational process. Thus, the student will be able to learn the subject while having a pleasant time, the anxiety of the student will be reduced with the game environment and the fear of failure will be overcome with the individualized learning. In this study, a snake game design was realized by using C\# programming language. This game was played by 123 students from 3rd and 4th grade students in basic education level. The aim of the study was to combine the four mathematical operations with the snake game and make the education fun. For this purpose, an educational snake game was designed and played by the students and the questionnaire related to the game was applied to 123 students attending 3rd and 4 th grades of primary education. The responses were evaluated statistically and the results were examined. According to the results of the research, $85 \%$ of the students stated that the study is useful in understanding the four operations in mathematics and developing what they know.
\end{abstract}

https://dx.doi.org/10.30855/gmbd.2019.03.03 


\section{INTRODUCTION (GIRIŞ)}

Technological advances lead to changes in people's interests and habits, perception and interpretation and learning methods [1], [2]. Along with the changing technology, the change that has started in many areas has also shown itself in the field of games and entertainment. With this change, the qualities of the games have also changed and today the concept of games is generally understood as computer games. One of the main reasons for this is that the computer has become an indispensable part of our lives. Nowadays, computer games, which are more preferred than other environments as an entertainment tool, attract the attention of people of all ages and players spend a lot of time on computer games. It was seen that World of Warcraft players spend 22.7 hours a week for the game. The total time spent on "Call of Duty Black Ops" exceeded 600 million hours within the first month after the game was released [3].

When learners are motivated by what they want to learn, they desire to spend time and effort for learning and use what they have learned in the future [4]. According to Malone, the use of computer games in education and training increases the motivation of learners [4], [5]. Therefore, an effective and efficient learning environment will be created by using computer games in education. Educational computer games are not only an interesting type of game, but also help students to develop their skills and include information about the course in which the game is prepared [6]. Students will learn about the subject and reinforce their previous knowledge while having a pleasant time with educational computer games [7]. Thus, educational computer games will increase the students' interest in the lessons and contribute to the permanent learning. Çankaya and Karamete[8] have designed an educational game about the ratio-ratio in mathematics for primary school students. Then, they examined the effect of the game they designed on the students' educational computer games and their attitudes about mathematics lesson. As a result, students' attitudes towards mathematics course with educational computer games were positive. Topçu ve ark. [9] conducted a study in order to reveal the opinions of prospective elementary school teachers about the use of educational computer games in the teaching of elementary mathematics. As a result of the research used qualitative research methods, prospective teachers stated that educational computer games would provide benefits such as visualizing concepts, developing thinking skills, learning by having fun, games endear mathematics lesson and learning more permanent.

According to Malone, who states that motivation is necessary for effective learning, intrinsic motivation factors must be present in the game to create a good and interesting computer game. These intrinsic motivation elements are fantasy, challenge and curiosity. Another intrinsic motivation is control [4], [10]. The high teaching capacity of these features in computer games reveals the necessity of using computer games in education and training. Bakar ve ark. [11] conducted a study to reveal students' views on the use of educational computer games in courses in formal education. They carried out the study during 9 weeks with the 6 th grade students who took social studies course. As a result of the research used qualitative research methods, it was stated that the use of educational games in social studies course increased the motivation of the students and the students liked the educational games. In addition, Ercan ve ark. [12] prepared a web-supported material called "kimyagerin sinifi" for 9th grade students. 54 students participated in the study and quasiexperimental research design was used in the study. Experimental research lasted 4 weeks and the results of the research indicated that there was a significant difference in the students' attitudes towards chemistry and academic achievement in favor of the experimental group.

Computer games offer an individualized learning environment that takes into account the student's interests and desires, appropriate for the level and could be arranged to the learning speed of the student. In addition, with the help of educational computer games, the student stays active during the game, which makes a significant contribution to the realization of permanent learning.

The time spent on the games is increasing in the world and in our country. In this study, an educational snake game was designed to convert the time spent on the game to a more productive process and to provide students with educational information in this period. It is aimed to develop four mathematical operations with the game of snake, which attracts people of all ages in the world. To this end, the player will use the numbers and operations on the playing field to obtain the desired number of points while playing the snake game. In this way, it will be possible to develop the students' mental computation skills, to provide education in a fun way and to provide effective and permanent learning with active participation. In 
addition, the player can choose a game that suits his / her own level in the study so that people of all ages can play educational snake game.

In this study, it is aimed to improve the four operations of 2 nd grade and above students, to reinforce their existing knowledge and to change their negative attitudes towards mathematics. For this purpose, a digital snake game was designed using C \# programming language to enable students to perform four operations in mathematics by playing games. The designed educational snake game was played by 123 students consisting of $3 \mathrm{rd}$ and 4 th grade students in primary school and a questionnaire was conducted with these students. With this survey, students' attitudes towards mathematics and game were tried to be determined and thus the effects of educational game on mathematics achievement and student motivation were evaluated and the results were presented as proportional and statistical.

\subsection{Digital Gaming (Dijital Oyun)}

The progress of technology day by day, urbanization, decreasing playgrounds and access to technology have changed the playing habits of children. Nowadays traditional games have been replaced by digital games which is playing in digital areas such as computers and phones. In the first time produced for entertainment purposes, digital games were used for educational purposes in the future. Digital games designed for educational purposes are called educational digital games[13].

\section{METHOD (YÖNTEM)}

\subsection{Working Group (Çalışma Grubu)}

The research related to the game design was carried out with 123 students randomly selected from the $3 \mathrm{rd}$ and 4th grade students of a primary school in Karatay district of Konya. 71 female and 52 male students participated in the survey. In the study, the distribution of male and female student were in balance.

\subsection{Game and Educational Computer Games (Oyun ve Eğitsel Bilgisayar Oyunlart)}

There is no definite definition for the game concept. Generally speaking, game is something that people do willingly and obligatory works are not games [14], [15]. According to Plensky, there are six basic elements that must be present in a game [16]. These are: rules, goals and objectives, outputs and feedbacks, competition / competition, interaction and story. Games are considered to have positive effects on the motivation of players [10]. With this motivation, players will be able to gain the information they need while they are playing the game. Games can be used in education as an alternative, complementary and enriching to other teaching methods [17]. According to Demirel et al., games are the software created in game format to improve students' problem solving competencies and to enable them to learn course topics [18]. If the educational games which contribute to the development of students' decision making, thinking and communication skills are well designed, the entertainment and learning process can be provided simultaneously. In this way, students will be more willing to learn the subject and an efficient learning will be provided. The fact that educational computer games are learned easily allows users of all ages to play these games.

\subsection{Four Operations with Educational Snake Game (Eğitsel Yulan Oyunu İle Dört İşlem Hesaplama)}

Educational snake game is a game designed for $2 \mathrm{nd}$ grade and above students to develop their skills for four mathematical operations and to reinforce their current knowledge.

It is thought that the anxiety about mathematics plays an important role in the failure of the students [19]. Students are afraid to make mistake in mathematics, so they avoid maths and then fail [20]. New methods such as direct expression and questionanswer techniques, which support traditional techniques and compatible with developing technology, should be preferred to eliminate prejudices against mathematics and to make students like mathematics [21]. The educational snake game designed for this purpose provides an environment that can create student-centered learning, motivate the student and increase his/her interest in the lesson.

With the educational snake game, each student will be able to play at an appropriate level for them. In this way, students' confidence will develop with questions that go from easy to difficult and fear of failure will be overcome. With the educational snake game, the student will be actively involved in the education process by having fun without being bored and by making and living. The fact that the student will be 
active during the game will make him interested in the lesson and the subjects will be more permanent.

The educational snake game is a game that students can learn while having fun. Before starting the game, the student will select a difficulty level in the screen that corresponds to his or her level. Figure 1 below shows the level scren.

7 educational snake

$-\quad \square \quad \times$

\section{EDUCATIONAL SNAKE v.2.3.8 EASY $\odot$ MEDIUM $\circ$ HARD START GAME}

Figure 1. Level Screen (Seviye Ekranı)

After the difficulty level is determined, the game window in Figure 2 will be displayed in which the player is asked the questions according to the difficulty level. The student will try to get the desired number by taking the numbers and the processes in the playing field with the snake. There is a time limit for this process. The sooner the student answers the desired number, the different points will be obtained according to the response time. In this way, the game will not be monotonous and the player will be able to participate more actively. Figure 2 below shows the screenshot of the educational snake game.

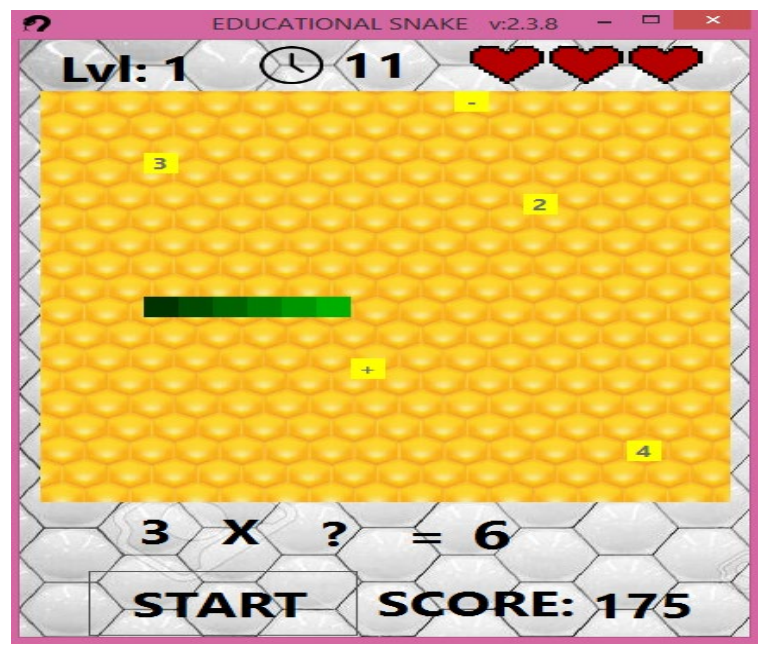

Figure 2. The screenshot of the educational snake game (Eğitsel yllan oyunu ekran görüntüsü)
Game so that continuity in the game is provided and it is aimed not to let the player leave the game in any wrong. If the desired number cannot be found or incorrectly answered in the educational snake game, one of the 3 lives given to the player will go away. The game will end when all 3 lives given to the player are completely over. In addition, the heart-shaped signs where bonus (difficult) questions are asked will appear on the playing field at certain stages of the game. If the player receives the bonus mark, a more difficult question will be asked to the player than the existing questions. When the player answers the question correctly, the player will receive an extra life and be awarded a higher score. Figure 3 below shows Bonus Question.

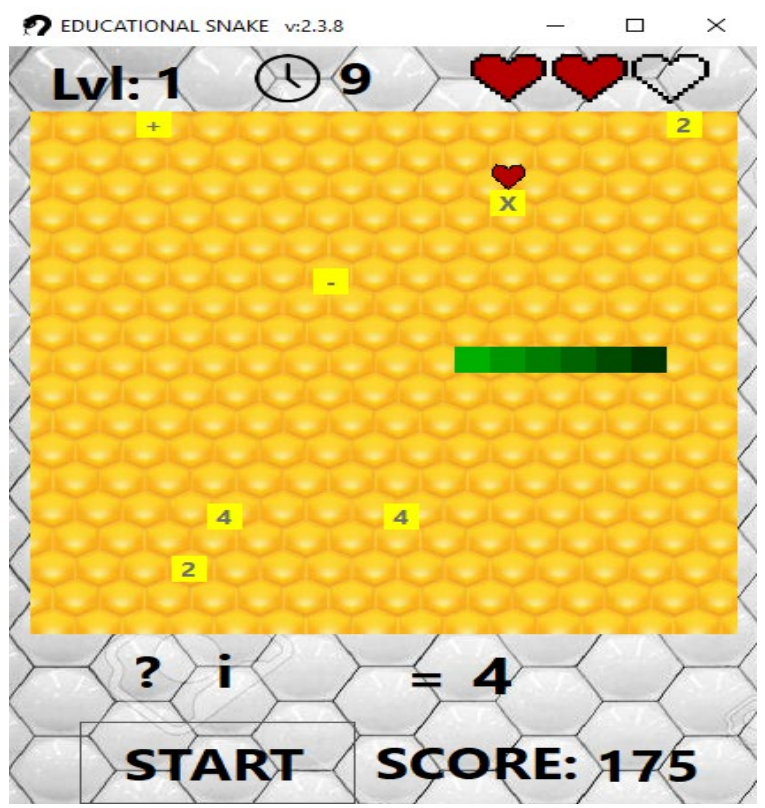

Figure 3. Bonus Question (Bonus Soru)

As the player answers the questions correctly, the difficulty level of the questions will increase at certain intervals according to the number and score of the questions answered correctly. As the level increases, the student will be able to see his / her level from the top left of the playing field. Thus, the player will not constantly face the same numbers and processes. It is aimed to improve the player continuously by increasing the difficulty level in certain stages of the game. There are 8 levels that the player can reach in each difficulty level determined at the beginning of the game. According to each difficulty level, the student is asked appropriate questions and processes. In this way, an individualized training will be provided for each student.

In the educational snake game, the players who lose all their lives will see a score window. In this 
window, the student will be able to register his / her name and see the scores of the other players and the highest rated player. Thus, the competitive environment which increases the motivation of the player, one of the elements of the game, will be provided.

Figure 4 below shows the screenshot of the educational snake game flow diagram .

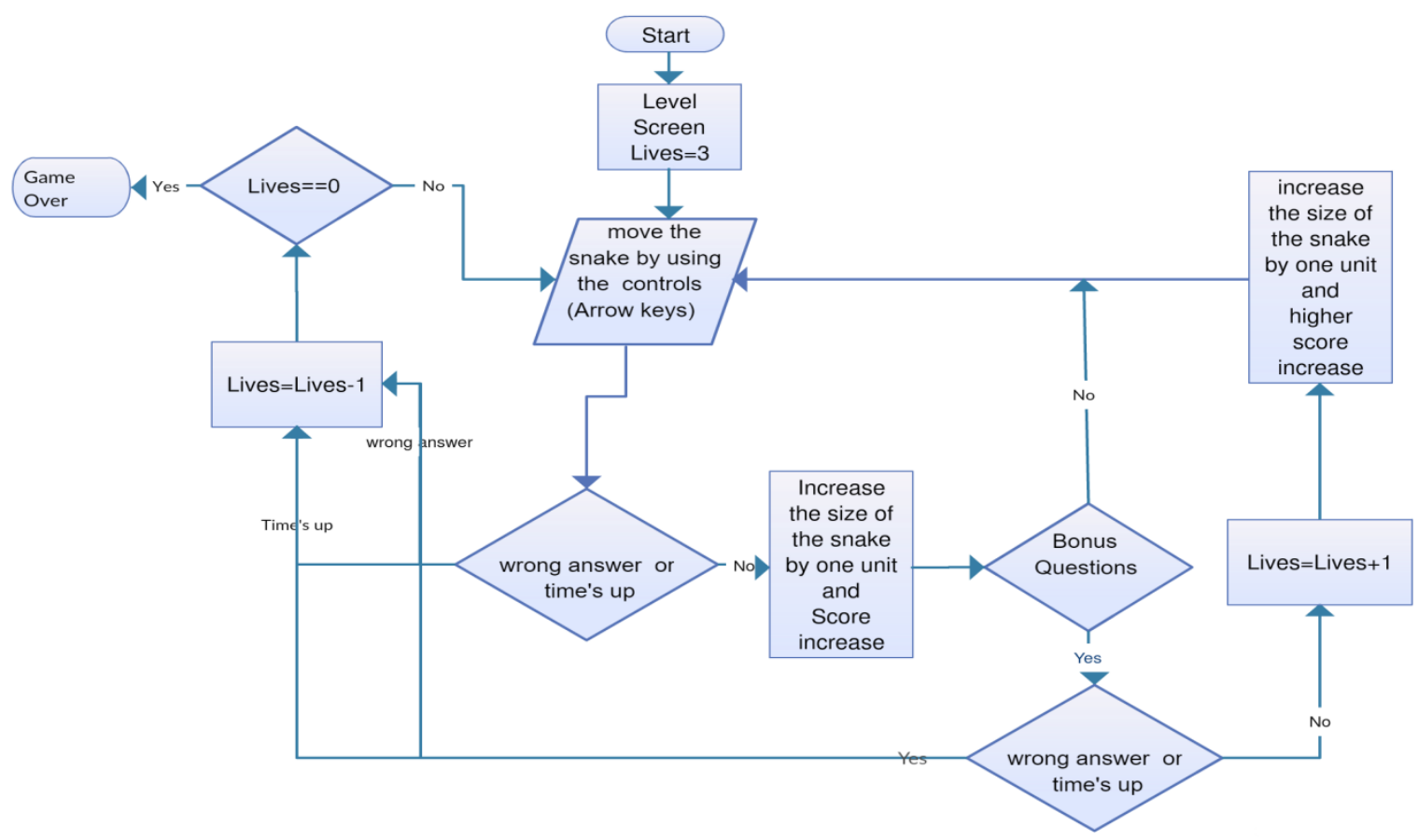

Figure 4. Educational snake game flow diagram (Ĕ̌itsel yılan oyunu akış diyagramı)

\section{FINDINGS (BULGULAR)}

The research on educational snake game was carried out with 123 students consisting of 3 rd and 4th grade students. 71 female and 52 male students participated in the survey. Students were informed about the study and educational snake game in advance. The percentage distribution of the questions asked to the students for the research and the answers given by the students are shown in Table 1 below.
Table 1. Research questions and results of educational snake game (Ë̆itsel yılan oyunu araştırma soru ve sonuçları)

\begin{tabular}{|c|c|c|c|c|}
\hline No & Questions & Yes & No & $\begin{array}{c}\text { Partl } \\
y\end{array}$ \\
\hline 1 & Do you like maths lesson? & 73 & 6 & 21 \\
\hline 2 & $\begin{array}{l}\text { Do you get bored during maths } \\
\text { lesson? }\end{array}$ & 13 & 65 & 22 \\
\hline 3 & $\begin{array}{l}\text { Do you use four operations well } \\
\text { in daily life? }\end{array}$ & 61 & 5 & 34 \\
\hline 4 & $\begin{array}{c}\text { Do you solve four operations } \\
\text { problems in mind? }\end{array}$ & 43 & 11 & 46 \\
\hline 5 & $\begin{array}{l}\text { Do you like playing computer } \\
\text { games? }\end{array}$ & 78 & 2 & 20 \\
\hline 6 & $\begin{array}{c}\text { Do you like educational computer } \\
\text { games? }\end{array}$ & 82 & 4 & 14 \\
\hline 7 & $\begin{array}{l}\text { Do you think using educational } \\
\text { games in maths is useful? }\end{array}$ & 70 & 11 & 19 \\
\hline 8 & $\begin{array}{c}\text { Do you get interested in lesson } \\
\text { more if games are used in four } \\
\text { operations? }\end{array}$ & 70 & 9 & 21 \\
\hline 9 & $\begin{array}{l}\text { Does the use of computer games } \\
\text { in maths help you like lesson and } \\
\text { make you more interested? }\end{array}$ & 76 & 6 & 18 \\
\hline 10 & $\begin{array}{l}\text { Did educational snake game help } \\
\text { you understand the lesson and } \\
\text { improve what you know? }\end{array}$ & 85 & 3 & 12 \\
\hline
\end{tabular}


According to the answers given to the survey questions of the students participating in the research, $73 \%$ of the students like mathematics. While the number of the students using four operations well in daily life was $61 \%$, this number decreased to $43 \%$ in solving four operations questions in mind. $70 \%$ of the students stated that it would be good to use computer games in mathematics lesson and four operations. Figure 5 below shows graphical representation of students' answers to research questions.

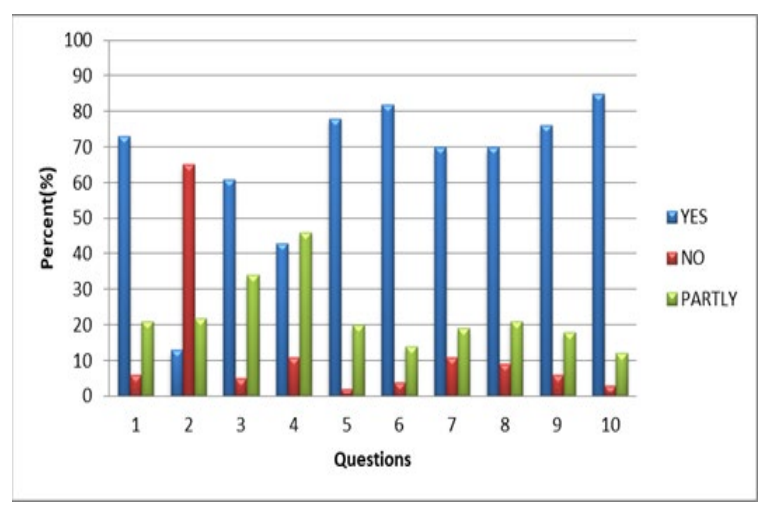

Figure 5. Response rates given to educational snake game survey questions (Eğitsel yllan oynnu anket sorularna verilen cevap oranlarl)

After playing the educational snake game, $85 \%$ of the students answered 'yes' to the question of whether the educational snake game was useful for students to understand the course and improve what they knew. During the interview, a student stated that there was not a game or interesting content in the courses, so the educational snake game was very good and he/she liked it. And another student said "Sometimes there are visual videos in science classes, but in math class there are no games or other content, I wish these games were made for all subjects".

As it was understood from the interviews with the students and the results of the survey, the students initially stated $70 \%$ positive opinion for the effect of the game on the lesson, and this ratio increased to $85 \%$ after playing the educational snake game. According to these results, the students could not express a definite opinion for the positive effect of the game on the lessons because they had never encountered such a game before, but after playing the game they reached a more definite conclusion. Supporting the mathematics course with different content attracted the students' interest and helped them to understand the contribution of the game to the lessons.

According to the research, $5 \%$ of the students who answered 'yes' to the question "Do you love mathematics?" said 'yes' to the question "Do you get bored during mathematical operations?" and $20 \%$ of them said 'partly' to the same question. $65 \%$ of these students answered 'yes' to the question " Do you use four operations well in daily life?" and $32 \%$ of them said 'partly'. $48 \%$ of them answered 'yes' to the question "Can you solve four operations questions in mind?" and $47 \%$ said 'partly'. $79 \%$ of the students who liked mathematics stated that it would be good to use games in mathematics, and $84 \%$ said that educational snake games were beneficial. According to these results, the level of active use of four operations by students who love mathematics is low and the rate of solving four operations questionsin mind is lower. With the educational snake game, it will be possible for the students who love mathematics to further develop their low skills for four operations. In addition, since they will actively perform mind gymnastics while playing games, the rate of solving math in mind, which is $48 \%$ among students, can be increased further. In 6 below, the percentage distribution of the answers given by some of the students who answered Yes to the question "Do you like mathematics?" is shown graphically. 


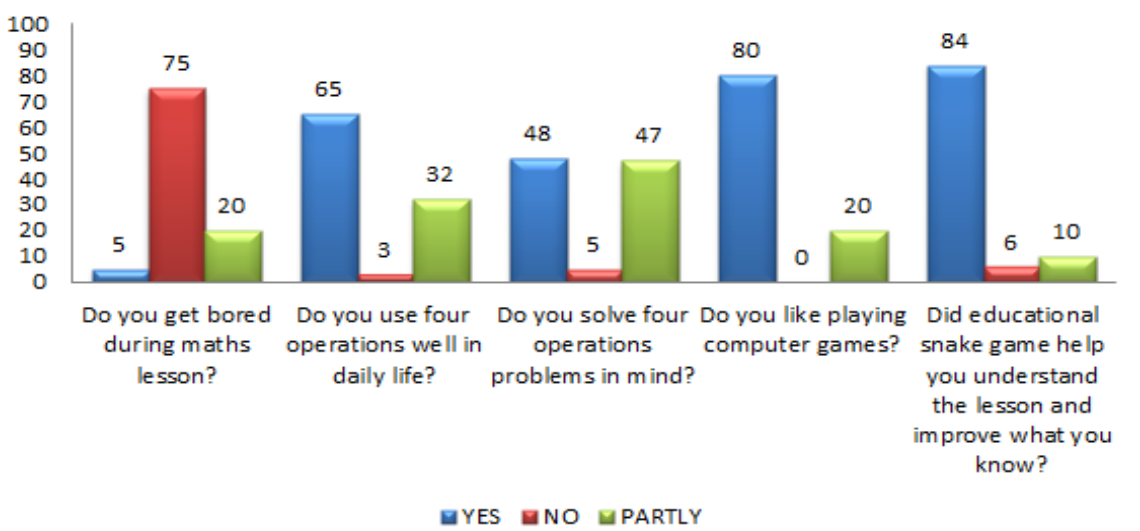

Figure 6. Response rate of the students who answered 'yes' to the question "Do you like mathematics?" ("Matematik dersini seviyor musunuz" sorusuna Evet diyen ögrenci cevap oranlarl)

The answers given by the students who answered 'partly' to the question "Do you like math lesson?" are as follows: While $29 \%$ of the students answered 'yes' to the question "Do you get bored while you are doing maths?", $38 \%$ of them answered 'partly'. $57 \%$ of them answered 'yes' to the question "Do you use four mathematical operations well in daily life?" and 43\% said 'partly.' $29 \%$ of them answered 'yes' to the question "Can you solve four operations questions in mind?" and $48 \%$ said 'partly.' $88 \%$ of these students stated that they liked to play computer games, and after playing the designed educational snake game, 95\% of them said 'yes' to the question "Did four mathematical operations game help you understand the lesson and improve what you know?" In 7 below, the percentage distributions of the answers given by some of the students who answered 'partly' to the question "Do you like maths lessons?" are shown graphically.

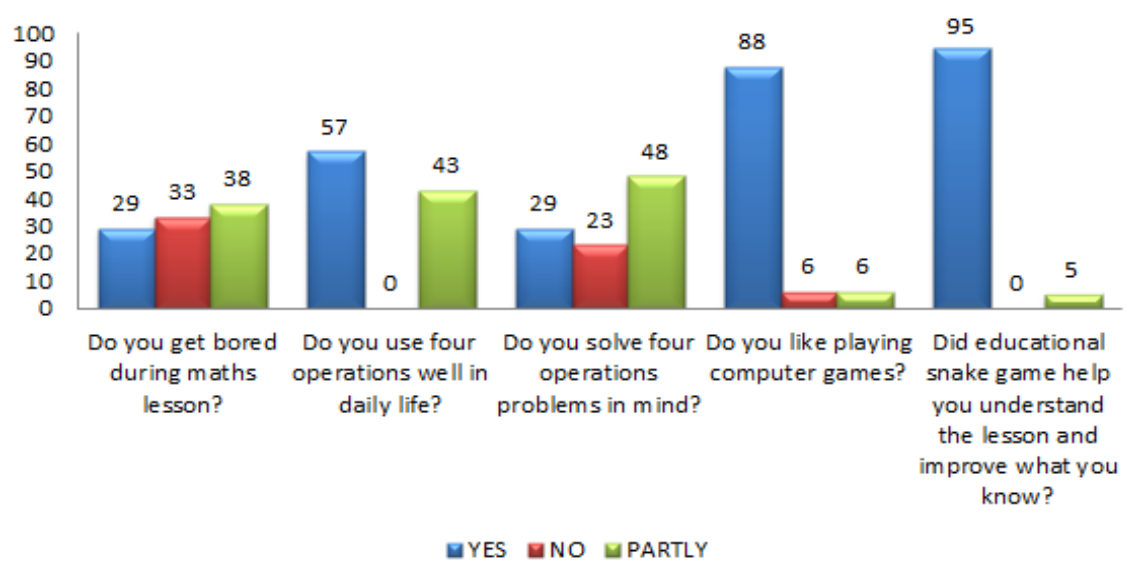

Figure 7. Response rates of the students who answered 'partly' to the question "Do you like maths lessons?" ("Matematik dersini seviyor musunuz” sorusuna Kısmen diyen öğrenci cevap oranlarl)

$80 \%$ of the students who answered 'no' to the question "Do you like maths?" said 'yes' to the question " Do you get bored while doing maths?" $17 \%$ of these students answered 'yes' to the question "Do you use four mathematical operaitons well in daily life?" and 33\% said 'partly' to the same question. $33 \%$ of the students answered 'yes' to the question "Can you solve four operations in mind?" and $33 \%$ of them said 'partly' to the same question.
Again, $83 \%$ of these students stated that they liked to play computer games. $83 \%$ of them said 'yes' to the question "Did four mathematical operations game help you understand the lesson and improve what you know?" Figure 8 below shows the proportional representation of the answers given by the students who answered 'No' to the question "Do you like mathematics?" 


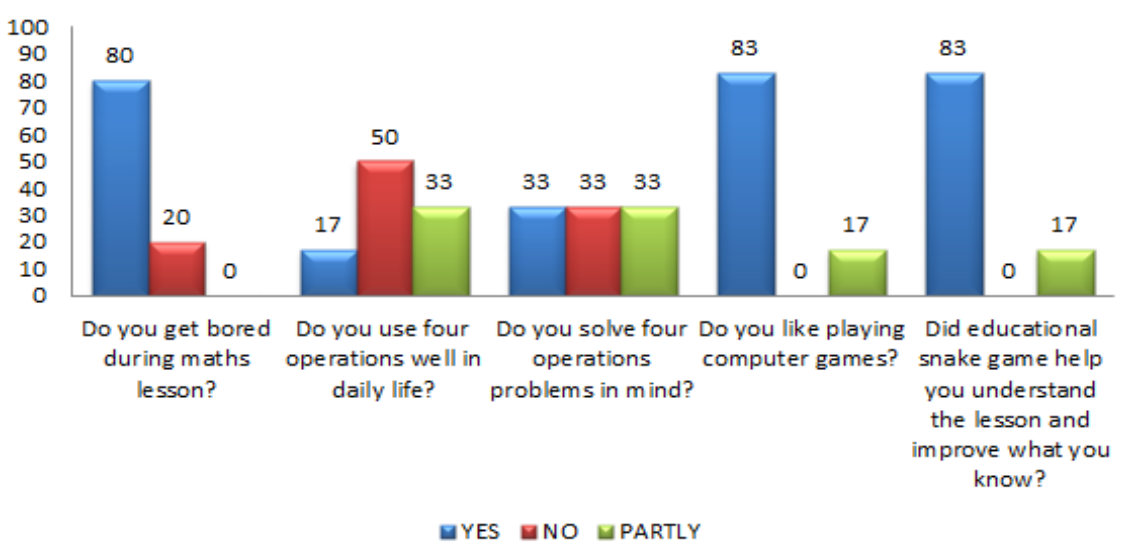

Figure 8. Response rates of the students who answered 'no' to the question "Do you like maths lessons? ("Matematik dersini seviyor musunuz” sorusuna Hayır diyen ögrenci cevap oranlarl)

According to the above results, computer games are a positive reinforcement for students. In addition, the educational snake game attracted the attention of the students and, since they never had such an experience before, they saw and understood that games could be used not only to spend time but to be useful. From all these results, it was seen that educational snake game had positive effects on students.

\section{CONCLUSION AND RECOMMENDATIONS (SONUÇLAR VE ÖNERILLER)}

According to the results of the research and faceto-face interviews with the students, as the students' interest in mathematics decreases, this attitude is manifested in all subjects related to mathematics even if it is easy or difficult. It was seen that the students with low interest in mathematics had a positive interest in computer games. In addition, it was observed that not only the students who did not like maths but all students were interested in computer games. According to these results, while educational computer game had a task of repeating the lesson, mind exercise and reinforcing the knowledge for students who loved mathematics lesson, it provided the ability to choose games according to the level and the questions from easy to difficult and it also sustained individual learning. In this way, as the students solved the questions with the game, their prejudices against the mathematics lesson decreased and they were able to overcome the feeling of not being able to solve the mathematical problems because they experienced the feeling of success.

According to the results of the research, $80 \%$ of the students like to play computer games and $85 \%$ of the students found the educational snake game successful. The children who play the designed snake game stated that this game is useful for understanding the lesson better and improving what they know.

With this kind of computer-aided digital games, the student will learn the subject in a pleasant environment. Game environment reduces anxiety in student, increases student's self-confidence and provides individual learning environment. The motivation of the student will increase with the games, and thus permanent learning will be realized. In addition, since the student is constantly active during the game, an effective and efficient learning will be provided. Because of all these benefits, game is an area that needs to be emphasized and studied in education.

\section{REFERENCES (KAYNAKLAR)}

[1] A. Kula and M. Erdem, "The effect of educational computer games in development of basic arithmetial operation skills", Hacettepe Üniversitesi Eğitim Fakültesi Dergisi, vol. 29, pp. 127-136, 2005.

[2] C. Eldem, N. Top, and H. Şahin, "Dijital İnsan Modelleri Kullanarak Otomobil Sürücüsü Duruş Pozisyonlarının Ergonomik Değerlendirilmesi Üzerine Bir Çalışma”, Gazi Mühendislik Bilimleri Dergisi (GMBD), vol. 5, no. 1, pp. 22-31, 2019.

[3] M. E. Korkusuz and A. Karamete, "Eğitsel oyun geliştirme modelleri”, Necatibey Eğitim Fakültesi Elektronik Fen ve Matematik Eğitimi Dergisi, vol. 7, no. 2, pp. 78-109, 2013. 
[4] T. W. Malone, "What makes things fun to learn? A study of intrinsically motivating computer games", ProQuest Information \& Learning, 1980.

[5] H. Tuzun, "Educational computer games and a case: Quest Atlantis", Hacettepe University Journal of Education, vol. 30, pp. 220-229, 2006.

[6] E. Bayirtepe and H. Tuzun, "The effects of gamebased learning environments on students' achievement and self-efficacy in a computer course", Hacettepe Universitesi Egitim Fakultesi DergisiHacettepe University Journal of Education, no. 33, pp. 41-54, 2007.

[7] R. M. Bottino, L. Ferlino, M. Ott, and M. Tavella, "Developing strategic and reasoning abilities with computer games at primary school level", Computers \& Education, vol. 49, no. 4, pp. 1272-1286, 2007.

[8] S. Çankaya and A. Karamete, "Eğitsel bilgisayar oyunlarının öğrencilerin matematik dersine ve eğitsel bilgisayar oyunlarına yönelik tutumlarına etkisi", Mersin Üniversitesi Eğitim Fakültesi Dergisi, vol. 4, no. 2, 2008.

[9] H. Topçu, S. Küçük, and Y. Göktaş, "Sınıf ögrretmeni adaylarının ilköğretim matematik öğretiminde eğitsel bilgisayar oyunlarının kullanımına yönelik görüşleri”, Turkish Journal of Computer and Mathematics Education (TURCOMAT), vol. 5, no. 2, pp. 119-136, 2014.

[10] R. Garris, R. Ahlers, and J. E. Driskell, "Games, motivation, and learning: A research and practice model", Simulation \& gaming, vol. 33, no. 4, pp. 441467, 2002.

[11] A. Bakar, H. Tüzün, and K. Çağıltay, "Öğrencilerin eğitsel bilgisayar oyunu kullanımına ilişkin görüşleri: Sosyal bilgiler dersi örneği”, Hacettepe Üniversitesi Eğitim Fakültesi Dergisi, vol. 35 , no. 35, pp. 27-37, 2008.

[12] O. Ercan, E. Ural, and D. Özateş, "Web Destekli Öğretimin Karıșımlar Konusunda Öğrencilerin Akademik Başarılarına ve Kimyaya Karşı Tutumlarına Etkisi The Effect of Web Assisted Teaching on Students' Achievement in the Subject of Mixtures and Attitudes towards Chemistry", Hacettepe Üniversitesi Eğitim Fakültesi Dergisi, vol. 31, no. 1, pp. 163-179, 2015.
[13] K. Kiili, "Digital game-based learning: Towards an experiential gaming model", The Internet and higher education, vol. 8, no. 1, pp. 13-24, 2005.

[14] H. Çamlıyer and H. Çamlıyer, "Eğitim bütünlüğü içinde çocuk hareket eğitimi ve oyun", Can Ofset, Manisa, 1997.

[15] U. Erkan, "İşlem Oyununun Yapay Zeka Destekli Simülasyonu, Gaziosmanpaşa Üniversitesi”, Fen Bilimleri Enstitüsü, Matematik Anabilim Dalı, Yüksek Lisans Tezi, Tokat, 2012.

[16] M. Prensky, "Fun, play and games: What makes games engaging", Digital game-based learning, vol. 5, no. 1, pp. 5-31, 2001.

[17] M. Çoban, Ö. Yıldırım, and Y. Göktaş, "Evaluation of Game Engines Used in Educational Games Design", $5^{\text {th }}$ International Computer \& Instructional Technologies Symposium, 2011, pp. 2224

[18] Ö. Demirel, S. S. Seferoğlu, and E. Yağc1, Öğretim teknolojileri ve materyal geliştirme. Pegem A Yayınc1l1k, 2004.

[19] K. Yenilmez and N. Özbey, “Özel okul ve devlet okulu öğrencilerinin matematik kaygı düzeyleri üzerine bir araştırma”, Uludağ Üniversitesi Eğitim Fakültesi Dergisi, vol. 19, no. 2, pp. 431-448, 2006.

[20] T. Hangül and Ü. Devrim, "The effect of the computer assisted instruction (CAI) on student attitude in mathematics teaching of primary school 8th class and views of students towards CAI", Necatibey Faculty of Education Electronic Journal of Science and Mathematics Education, vol. 4, no. 2, pp. 154$176,2010$.

[21] H. İncekara, B. Tezcan, S. Alan and Ş. Taşdemir, "Educational Design of A Snake Game For Basic Mathematical Operations With A Different Approach", Education Research Highlights in Mathematics, Science and Technology 2017:ISRES Publishing, 2017, pp. 48-53. 


\section{Hayri İNCEKARA}

Hayri İncekara was born in Konya, Turkey, 1986. After he graduated from highschool in Konya he went to Gazi University in Ankara and he completed his B.S. at there in 2008. In 2008, he attended the MSc programme at the Electronic and Computer Systems Training Department in Selçuk University and graduated in 2010. Selcuk University is continuing his $\mathrm{PhD}$ education in Information Technology Engineering. His current fields of research are control, artificial intelligence, programming languages, unmanned aerial vehicles and robotics.

\section{Şakir TAŞDEMIR}

Şakir Taşdemir was born in Sinop in the year of 1971. After he graduated from highschool in Sinop he went to Gazi University in Ankara and he completed his B.S. at there in 1994. Then he studied and completed his M.S. at Selçuk University in 2004. After this he finally had his Ph.D. from Selçuk University, Graduate School of Natural Sciences, Department of Electrical-Electronic Engineering in 2010. As a result of his education and accomplishments he possesses the technical skills such as image processinganalysing, ability to work on the field of Artificial Intelligence, digital game designing and programming mobil programming (for android), web programming (HTML-PHP-MYSQL). 